\title{
Copper(II) Coordination Compounds with Methanoato and Pyridine Ligands: Conversion from Mononuclear to Polynuclear in the Presence of Moisture
}

\author{
Amalija Golobič, Fedja Marušič, Primož Šegedin and Marta Počkaj \\ Faculty of Chemistry and Chemical Technology, University of Ljubljana, Večna pot 113, \\ 1000 Ljubljana, Slovenia. \\ *Corresponding author: E-mail: marta.pockaj@fkkt.uni-lj.si.
}

Received: 08-12-2019

\begin{abstract}
Blue prismatic crystals of mononuclear $\left[\mathrm{Cu}^{\mathrm{II}}\left(\mathrm{O}_{2} \mathrm{CH}\right)_{2}(\mathrm{Py})_{3}\right]\left(\mathrm{Py}=\right.$ pyridine, $\left.\mathrm{C}_{5} \mathrm{H}_{5} \mathrm{~N}\right)$, 1, were prepared from reaction solution containing dry pyridine and dinuclear $\left[\mathrm{Cu}_{2}{ }^{\mathrm{II}}\left(\mathrm{O}_{2} \mathrm{CH}\right)_{4}(\mathrm{Py})_{2}\right]$. When a portion of solution together with crystals was exposed to air moisture, crystals of $\mathbf{1}$ dissolved in mother liquid. Simultaneously, blue needles of 2, i.e. covalently linked one-dimensional chain structure with formula $\left[\mathrm{Cu}\left(\mathrm{O}_{2} \mathrm{CH}\right)_{2}(\mathrm{Py})_{2}\right]_{n} \cdot n \mathrm{H}_{2} \mathrm{O}$, grew out of the solution. The process lasted few minutes and was observed under optical microscope. The conversion from $\mathbf{1}$ to $\mathbf{2}$ takes place also outside of solution in the solid state. Single crystal X-ray diffraction data were collected at $150 \mathrm{~K}$ for $\mathbf{1}$ and after that for $\mathbf{2}$, originating from the same reaction solution. This paper reports the structures of both compounds. Alternative synthesis method of $\mathbf{2}$ arising from a mixture of copper methanoate and pyridine is also reported.
\end{abstract}

Keywords: Copper(II) methanoates; pyridine; crystal structure determination; structure conversion

\section{Introduction}

The coordination chemistry of copper(II) with different carboxylate ligands is very diverse, mainly due to the versatility of coordination modes of carboxylate ligand which with its four lone electron pairs can be coordinated to 1-4 metal centres. ${ }^{1}$ Additionally, different alkyl chain lengths of different carboxylates represent a greater or lesser sterical obstacle on a way to a formation of complex molecules. However, the smallest carboxylate ligand, i.e. methanoate anion, is thus the one with the least steric influences. If additional $\mathrm{N}$-donor ligand from the family of (substituted) pyridines is introduced besides the methanoato ligand, the diversity of the obtained crystal structures further increases. In this case, mononuclear, dinuclear paddle-wheel like or polynuclear coordination moieties are formed. ${ }^{2}$ Interestingly, only four crystal structures of copper(II) with pyridine and methanoato ligand are listed in CSD, i.e. mononuclear $\left[\mathrm{Cu}\left(\mathrm{O}_{2} \mathrm{CH}\right)_{2}(\mathrm{Py})_{2}\left(\mathrm{H}_{2} \mathrm{O}\right)_{2}\right]$ (refcode AFMPCA $)^{3}$, dinuclear paddle-wheel $\left[\mathrm{Cu}_{2}\left(\mathrm{O}_{2} \mathrm{CH}\right)_{4}\right.$ $\left.(\mathrm{Py})_{2}\right](\text { refcode AFMPCB })^{3}$, and polynuclear $\left[\mathrm{Cu}\left(\mathrm{O}_{2} \mathrm{CH}\right)_{2}\right.$ $\left.(\mathrm{Py})_{2}\right]_{n} \cdot n \mathrm{H}_{2} \mathrm{O}$ (refcodes FORPCU and FORPCU01). ${ }^{3,4}$ Crystal structures with substituted pyridines are more frequent, e.g. with 2-methylpyridine, ${ }^{5,6} 3$-methylpyridine, ${ }^{6,7}$ 4-methylpyridine, ${ }^{6}$ 2,6-dimethylpyridine, ${ }^{8} 3$-hydroxypyridine, ${ }^{9} 4$-aminopyridine, ${ }^{10}$ etc.

In this paper, the synthesis and characterization of two copper(II) coordination compounds with methanoato and pyridine ligands is described. In both compounds, the coordination number of central copper(II) is five, which is less usual than four- or sixfold coordination. ${ }^{11-13}$

\section{Experimental}

\section{1. Materials and Measurements}

All reagents and chemicals were purchased from commercial sources and used without further purification. The identity of the intermediate compounds was proven by means of X-ray powder diffraction (see Supplementary Information). $\mathrm{CHN}$ elemental analyses were performed with a Perkin-Elmer $2400 \mathrm{CHN}$ Elemental Analyzer. The amount of copper was determined electrogravimetrically with Pt electrodes. The infrared spectra were measured on solid samples using a Perkin-Elmer Spectrum 100 series FT-IR spectrometer equipped with ATR. Electronic spectra were recorded as nujol mulls and also as solutions (water, acetonitrile, methanol, DMSO) on Perkin Elmer UV/ VIS/NIR Spectrometer Lambda 19 between 200 and 860 
nm. Magnetic susceptibility of the substance was determined at room temperature by the Evans method using powdered sample and a Sherwood Scientific MSB-1 balance with $\mathrm{HgCo}(\mathrm{NCS})_{4}$ as a calibrant. Diamagnetic corrections were estimated from Pascal's constants and the effective magnetic moment was calculated using the equation: $\mu_{\mathrm{eff}}=2.828(\chi \mathrm{MT})^{1 / 2}$.

\section{2. Syntheses}

$\boldsymbol{a}-\mathrm{Cu}\left(\mathrm{O}_{2} \mathrm{CH}\right)_{2}$ was synthesized via modified published synthesis pathway. ${ }^{14}$ To concentrated $\mathrm{HCOOH}$ $(11.9 \mathrm{~mL})$, water $(0.8 \mathrm{~mL})$ and powdered $\mathrm{Cu}_{2}(\mathrm{OH})_{2} \mathrm{CO}_{3}$ $(2.0 \mathrm{~g}, 9.0 \mathrm{mmol})$ were added. The reaction mixture was refluxed for one hour, and left in the refrigerator at approx. $5{ }^{\circ} \mathrm{C}$ overnight. Dark blue crystalline product was filtered off, dried in the air for 20 minutes and additionally in a desiccator over solid $\mathrm{KOH}$ for 24 hours. Yield: $95 \%$.

$\left[\mathrm{Cu}_{\mathbf{2}}\left(\mathrm{O}_{\mathbf{2}} \mathbf{C H}\right)_{4}(\mathrm{Py})_{2}\right]$ was prepared from $\alpha-\mathrm{Cu}\left(\mathrm{O}_{2} \mathrm{CH}\right)_{2}$ $(1.0 \mathrm{~g}, 6.5 \mathrm{mmol})$, pyridine $(1.2 \mathrm{~mL}, 14.9 \mathrm{mmol})$ and acetonitrile $(20 \mathrm{~mL})$. The reaction mixture was stirred at room temperature for two hours. The obtained green powder was filtered off, dried in the air for 20 minutes and additionally in a desiccator over solid $\mathrm{KOH}$ for 24 hours. Yield: $88 \%$.

$\left[\mathrm{Cu}\left(\mathrm{O}_{2} \mathbf{C H}\right)_{2}(\mathbf{P y})_{3}\right](\mathbf{1})$. The flask with $10 \mathrm{~mL}$ of dry pyridine (dried with $\mathrm{KOH}$ ) was placed in an inert atmosphere and purged with argon. While stirring, $0.40 \mathrm{~g}$ of powdered $\left[\mathrm{Cu}_{2}\left(\mathrm{O}_{2} \mathrm{CH}\right)_{4}(\mathrm{Py})_{2}\right]$ was added. The flask was put into an oil bath which was heated to $50{ }^{\circ} \mathrm{C}$. After 10 min the reaction solution was poured through the filter paper, the flask with the filtrate was sealed and put in the refrigerator at approx. $5{ }^{\circ} \mathrm{C}$. After one month the blue prisms were obtained, suitable for X-ray structural analysis. The compound $\mathbf{1}$ is very sensitive to the presence of moisture. Crystals of $\mathbf{1}$ were stable for several weeks, if they were kept in a hermetically sealed container. Upon exposure to air moisture, the crystals of $\mathbf{1}$ transformed into $\mathbf{2}$ very quickly. Thus, the other analyses of $\mathbf{1}$, with exception of single crystal X-Ray structural analysis could not be performed.

$\left[\mathrm{Cu}\left(\mathrm{O}_{2} \mathrm{CH}\right)_{2}(\mathrm{Py})_{2}\right]_{n} \cdot n \mathrm{H}_{2} \mathrm{O}$ (2). Compound 2 was prepared in two different ways:

A) $0,75 \mathrm{~g} \mathrm{a}-\mathrm{Cu}\left(\mathrm{O}_{2} \mathrm{CH}\right)_{2}$ was added into $10 \mathrm{~mL}$ of pyridine while stirring. The reaction mixture was cautiously heated until the previously blue solution became dark violet. At that time the hot solution was poured through the filter paper. The filtrate was left to stand in the refrigerator at approx. $5{ }^{\circ} \mathrm{C}$ for 24 hours. After that time blue needle like crystals grew in the solution which were filtered off and dried in air. Diffraction image of selected single crystal showed that the unit cell of product corresponded to that of compound 2. This identification was further confirmed by taking powder diffraction pattern using Guinier-De Wolf camera. Yield: $68 \%$. Anal. Calc. for $\mathrm{C}_{12} \mathrm{H}_{14} \mathrm{CuN}_{2} \mathrm{O}_{5}$ : C, 43.70; H, 4.28; N, 8.50; $\mathrm{Cu}, 19.27$.
Found: C, 43.53; H, 4.36; N, 8.46; Cu, 19.15. Magnetic susceptibility (RT): $\mu_{\text {eff }}, 1.83 \mathrm{BM}$. IR: $v_{\text {asym }}\left(\mathrm{CO}_{2}\right), 1626,1589$, $1579 \mathrm{~cm}^{-1}, v_{\text {sym }}\left(\mathrm{CO}_{2}\right), 1326 \mathrm{~cm}^{-1}$. UV-VIS (nujol): $\lambda_{\max }$ $638,270 \mathrm{~nm}$.

B) The single crystals of $\mathbf{2}$ were obtained also from $\mathbf{1}$ as follows. Single crystals of $\mathbf{1}$ together with the mother liquid were left in the open Petri dish. After few minutes, the crystals of $\mathbf{1}$ dissolved completely and single crystals of $\mathbf{2}$ grew out of the reaction solution. Such single crystal of $\mathbf{2}$ was used for structural determination described in this paper.

\section{3. X-Ray Crystallography}

For X-ray structure determination, the single crystals of both compounds were surrounded by silicon grease, mounted on the tip of glass fibres and transferred to the goniometer head in the stream of liquid nitrogen. For compound 2, the single crystal obtained by decomposition of $\mathbf{1}$ as well as the one obtained by procedure $\mathrm{B}$ was used to prove that both possess the same crystal structure (the data included in this paper refer to the single crystal of 2 that was prepared from 1). Diffraction data for structure analysis were collected on a Nonius Kappa CCD diffractometer using Nonius COLLECT software and monochromated Mo Ka radiation at $150 \mathrm{~K} .{ }^{15}$ Data reduction and integration were performed with the DENZO-SMN program suite. ${ }^{16}$ The initial structural model containing coordination molecule was obtained via direct methods using the SIR97 structure solution program. ${ }^{17} \mathrm{~A}$ full-matrix least-squares refinement on $F^{2}$ magnitudes with anisotropic displacement parameters for all non-hydrogen atoms using SHELXL-2013 was employed. ${ }^{18}$ All $\mathrm{H}$ atoms were initially located in difference Fourier maps and were further treated as riding on their parent atoms with $\mathrm{C}$ (aromatic) $-\mathrm{H}$ distance of $0.93 \AA$ A The oxygen of water molecule is symmetry disordered due to its position near mirror plane in 2, while the hydrogen atoms bound to it lie on a mirror plane. The positions of both hydrogens were obtained from a difference Fourier map and refined using AFIX 3 command: only their displacement parameters were refined using the $U_{\text {iso }}(\mathrm{H})=$ $1.2 U_{\text {eq }}(\mathrm{O})$ constraint. Details on crystal data, data collection and structure refinement are given in Table 1. Figures depicting the structures were prepared with ORTEP3 and Mercury. ${ }^{19}, 20$

\section{Results and Discussion}

In a symmetrical coordination molecule of 1 (Fig. 1) in which a twofold axis runs through atoms $\mathrm{Cu} 1-\mathrm{N} 2-$ C9, the central copper(II) atom is surrounded by three pyridine molecules and two monodentately bound methanoato ligands. Thus the coordination number is five, and the value of $\tau_{5}$ parameter $^{21}(0.29)$ confirms that 
Table 1. Crystal data, data collection and structure refinement.

\begin{tabular}{lll}
\hline Crystal data & $\mathbf{1}$ & $\mathbf{2}$ \\
\hline Formula & $\mathrm{C}_{17} \mathrm{H}_{17} \mathrm{CuN}_{3} \mathrm{O}_{4}$ & $\mathrm{C}_{12} \mathrm{H}_{14} \mathrm{CuN}_{2} \mathrm{O}_{5}$ \\
$M_{\mathrm{r}}$ & 390.87 & 329.79 \\
Cell setting, space group & monoclinic, $C 2 / c$ & orthorhombic, Pnma \\
$a(\AA)$ & $12.2422(2)$ & $9.6528(2)$ \\
$b(\AA)$ & $9.5968(2)$ & $14.1667(3)$ \\
$c(\AA)$ & $15.5626(4)$ & $10.3540(2)$ \\
$\beta\left({ }^{\circ}\right)$ & $108.8790(10)$ & 90 \\
$V\left(\AA^{3}\right)$ & $1730.03(6)$ & $1415.89(5)$ \\
$Z$ & 4 & 4 \\
$D_{\mathrm{x}}\left(\mathrm{Mg} \mathrm{m}^{-3}\right)$ & 1.501 & 1.547 \\
$\mu\left(\mathrm{mm}^{-1}\right)$ & 1.289 & 1.562 \\
$F(000)$ & 804 & 676 \\
Absorption correction & multi-scan & multi-scan \\
No. of measured, independent & & \\
and observed reflections & $12534,1975,1741$ & $20392,1688,1454$ \\
$R_{\text {int }}$ & 0.045 & 0.039 \\
$R\left(\right.$ on $\left.F_{\text {obs }}\right), w R$ (on $\left.F_{\text {obs }}\right), S$ & $0.0304,0.0658,1.078$ & $0.0265,0.0669,1.108$ \\
No. of contributing reflections & 1975 & 1688 \\
No. of parameters & 115 & 108 \\
$\Delta \rho_{\text {max }}, \Delta \rho_{\text {min }}\left(\mathrm{e} \AA^{-3}\right)$ & $0.33,-0.47$ & $0.33,-0.42$ \\
\hline
\end{tabular}

the central ion lies in a distorted square pyramidal environment as usual for copper(II) compounds with such coordination number. The two pyridines as well as the two methanoates in a basal plane of the square pyramid are positioned trans to each other. The methanoato ligand is slightly closer than the basal pyridine: the corresponding distances are 1.9716(13) $\AA$ for $\mathrm{Cu} 1-\mathrm{O} 1$ and 2.0391(15) $\AA$ for Cu1-N1. The coordination bond to the apical pyridine ligand is prolonged in comparison with these from basal plane (2.246(2) $\AA, \mathrm{Cu} 1-\mathrm{N} 2)$. Data on selected bond lengths and angles for $\mathbf{1}$ are given in Table 2.

Table 2. Selected bond lengths and angles $\left(\AA{ }^{\circ}\right)$ for $\mathbf{1}$ and $\mathbf{2}$.

\begin{tabular}{lrcr}
\hline 1 & & & \\
$\mathrm{Cu} 1-\mathrm{O} 1$ & $1.972(1)$ & $\mathrm{O} 1-\mathrm{Cu} 1-\mathrm{N} 1$ & $92.09(6)$ \\
$\mathrm{Cu} 1-\mathrm{N} 1$ & $2.039(2)$ & $\mathrm{O} 1-\mathrm{Cu} 1-\mathrm{N} 1^{i}$ & $88.95(6)$ \\
$\mathrm{Cu} 1-\mathrm{N} 2$ & $2.246(2)$ & $\mathrm{O} 1-\mathrm{Cu} 1-\mathrm{N} 2$ & $87.32(4)$ \\
$\mathrm{O} 1-\mathrm{Cu} 1-\mathrm{O} 1^{i}$ & $174.63(8)$ & $\mathrm{N} 1-\mathrm{Cu} 1-\mathrm{N} 2$ & $101.25(4)$ \\
$\mathrm{N} 1-\mathrm{Cu} 1-\mathrm{N1}^{i}$ & $157.49(9)$ & & \\
$\mathbf{2}$ & & & \\
$\mathrm{Cu} 1-\mathrm{O} 1$ & $1.954(2)$ & $\mathrm{Cu} 1-\mathrm{O} 4^{i i}$ & $1.975(2)$ \\
$\mathrm{Cu} 1-\mathrm{O} 3$ & $2.281(2)$ & $\mathrm{Cu} 1-\mathrm{N} 1$ & $2.019(2)$ \\
$\mathrm{N} 1-\mathrm{Cu} 1-\mathrm{N} 1^{i i i}$ & $169.79(8)$ & $\mathrm{O} 3-\mathrm{Cu} 1-\mathrm{N} 1$ & $94.78(4)$ \\
$\mathrm{O} 1-\mathrm{Cu} 1-\mathrm{O} 4^{i i}$ & $177.85(7)$ & $\mathrm{O} 3-\mathrm{Cu} 1-\mathrm{O} 4^{i i}$ & $84.18(6)$ \\
$\mathrm{O} 1-\mathrm{Cu} 1-\mathrm{N} 1$ & $91.48(4)$ & $\mathrm{O} 4^{i i}-\mathrm{Cu} 1-\mathrm{N} 1$ & $88.70(4)$ \\
$\mathrm{O} 1-\mathrm{Cu} 1-\mathrm{O} 3$ & $93.67(6)$ & & \\
\hline
\end{tabular}

Symmetry codes: $(i)-x, y,-z+1 / 2 ;$ (ii) $x-1 / 2, y,-z+1 / 2$; (iii) $x,-y+$ $1 / 2, z$.

When exposed to water, even in traces from the air, the crystal structure 1 converts into more symmetrical 2 with the formula $\left[\mathrm{Cu}\left(\mathrm{O}_{2} \mathrm{CH}\right)_{2}(\mathrm{Py})_{2}\right]_{n} \cdot n \mathrm{H}_{2} \mathrm{O}$, in which $\mathrm{Cu}(\mathrm{II})$ and both methanoates as well as the hydrogen atoms from water molecule lie on a mirror plane. The central $\mathrm{Cu}(\mathrm{II})$ atom in $\mathbf{2}$ remains five-coordinate in a shape of distorted square pyramid with parameter value $\tau_{5}=0.14$ (Fig. 2). ${ }^{21}$ As in 1 , the basal plane is defined by two nitrogens from two pyridine molecules and two oxygens from two methanoato ligands. Similarly, pyridines as well as the methanoates are positioned trans to each other. The deviations from the basal mean plane are significantly smaller than in $\mathbf{1}$. One of the two symmetry independent methanoato ligands is monodentate (Cu1-O1 1.954(2) ̊̊), while the other acts as a bidentate bridge between the adjacent $\mathrm{Cu}(\mathrm{II})$ atoms in a syn-anti mode. The corresponding distances $\mathrm{Cu} 1-\mathrm{O} 4^{i}$ and $\mathrm{Cu} 1-\mathrm{O} 3$

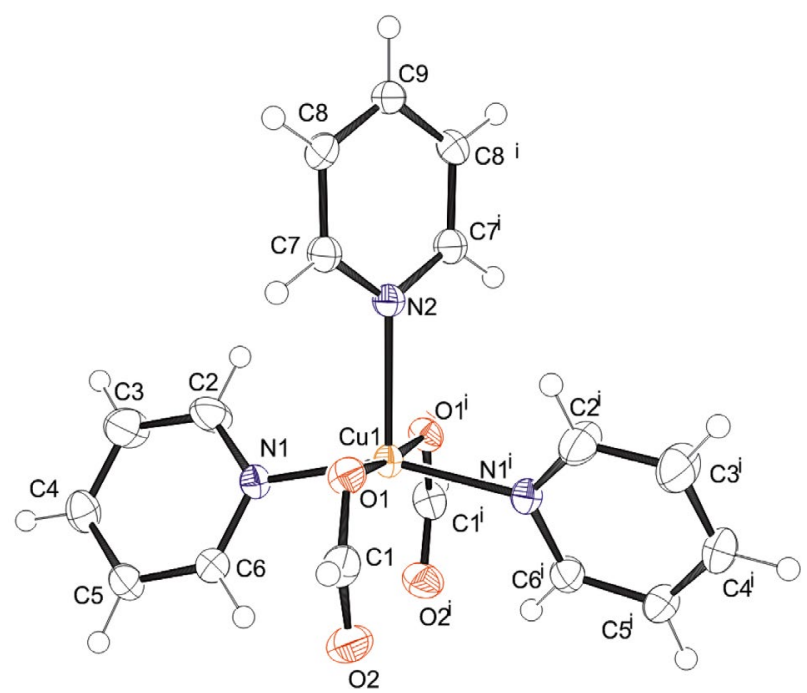

Figure 1. The ORTEP representation of coordination molecule in $\mathbf{1}$. (i) $-x, y,-z+1 / 2$. 
are 1.975(2) and 2.281(2) $\AA$, respectively $(i=x-1 / 2, y,-z+$ $1 / 2$ ). As in 1 , the distances between $\mathrm{Cu} 1$ and equatorial O-ligands are shorter than towards the apical one. With the assistance of the bridging methanoato ligand, infinite chains of $\left[\mathrm{Cu}\left(\mathrm{O}_{2} \mathrm{CH}\right)_{2}(\mathrm{Py})_{2}\right]_{n}$ running parallel to the crystallographic $a$ axis are formed (Fig. 7d). Water molecules are hydrogen bonded to $\mathrm{O}$ atoms of two methanoato ligands from the neighboring coordination moieties of the same chain. In this way the structure is additionally stabilized. The geometry of hydrogen bonds is presented in Table 3.

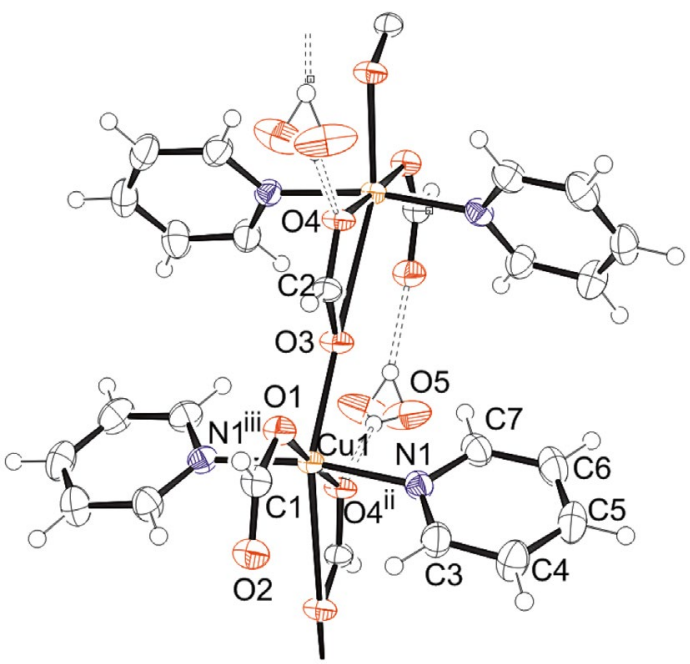

Figure 2. The ORTEP representation of coordination environment of $\mathrm{Cu}(\mathrm{II})$ in 2 and a formation of chains. ( $i i=x-1 / 2, y,-z+1 / 2$; $i i i=$ $x,-y+1 / 2, z)$. Dashed lines represent hydrogen bonds. on Fig. 4. The single crystal experiment was run on opaque crystal, from which the powder pattern was extracted afterwards. The obtained powder pattern has shown the presence of compound $\mathbf{2}$ and the absence of 1 very clearly (Fig. 5). The same changes were observed with single crystal of 1, used for data collection at $150 \mathrm{~K}$. The crystal was extensively surrounded by vacuum grease which to some
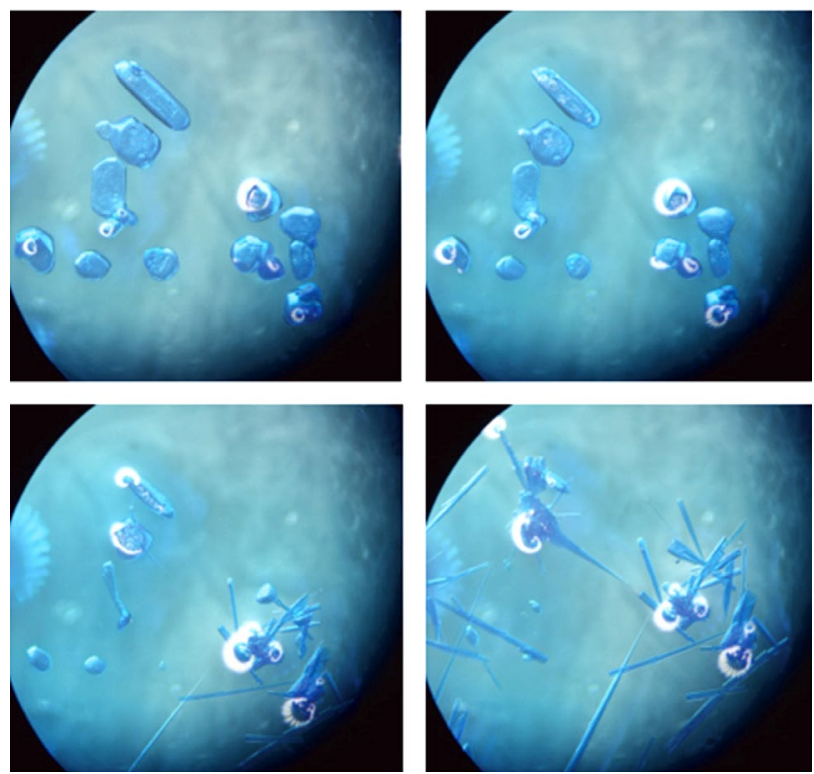

Figure 3. The conversion of blue prisms of $\mathbf{1}$ to needle-like crystals of $\mathbf{2}$ in mother liquor. The identity of the crystals was confirmed by the determination of unit cell parameters.

Table 3. Hydrogen bond geometry in 2 .

\begin{tabular}{|c|c|c|c|c|c|}
\hline D-H $\cdots A$ & D-H (A) & 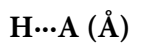 & $\mathbf{D} \cdots \mathbf{A}(\AA)$ & D-H...A $\left(^{\circ}\right)$ & Symmetry code of A \\
\hline $\mathrm{O} 5-\mathrm{H} 5 \mathrm{~A} \cdots \mathrm{O} 4$ & 0.85 & 2.01 & $2.757(3)$ & 145.5 & $x-1 / 2, y,-z+1 / 2$ \\
\hline $\mathrm{O} 5-\mathrm{H} 5 \mathrm{~B} \cdots \mathrm{O} 2$ & 0.87 & 1.97 & $2.749(3)$ & 147.6 & $x+1 / 2, y,-z+1 / 2$ \\
\hline
\end{tabular}

The structure of $\mathbf{2}$ was previously described (refcodes FORPCU and FORPCU01) $)^{3,4}$ but both crystal structures were determined at room temperature whereas ours was performed at $150 \mathrm{~K}$. Low temperature and room temperature unit cell parameters and atoms' coordinates are similar, consequently the arrangement of atoms is basically the same. Disorder of water molecules is present also at $150 \mathrm{~K}$, probably indicating the static nature of disorder.

The structure conversion process from 1 to 2 was relatively fast. When the mother liquor with the crystals of $\mathbf{1}$ was exposed to air, it took approximately 15 minutes for the following changes to happen. At first, the prismatic blue crystals of $\mathbf{1}$ dissolved in mother liquid. At the same time, new needle-like blue crystals of 2 were growing out of the solution (Fig. 3). The conversion from 1 to 2 took place also outside of the solution, i.e. in the solid state, when crystals of $\mathbf{1}$ were left in air on a filter paper. Visual change from optically clear to opaque crystals can be seen extent protected its exposure against moisture and thus slowed down the conversion process. After $24 \mathrm{~h}$ at ambient temperature, the single crystal experiment was repeated and the powder pattern extracted from it. As shown in Fig. S3, the structure conversion from $\mathbf{1}$ to $\mathbf{2}$ can be confirmed.
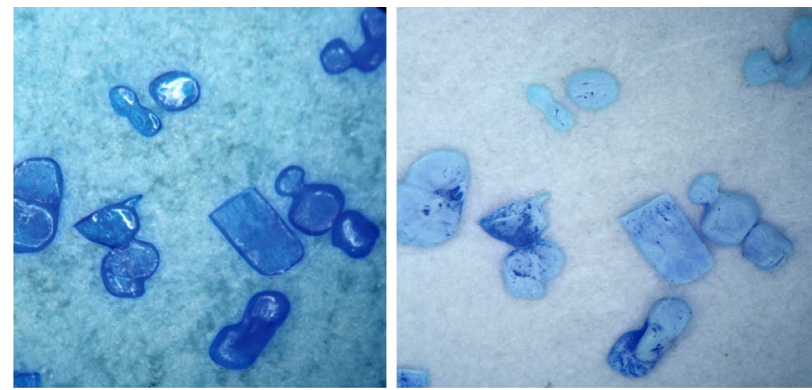

Figure 4. Prismatic crystals of $\mathbf{1}$ just after taking out of the solution (left) and getting opaque after few minutes (right). 

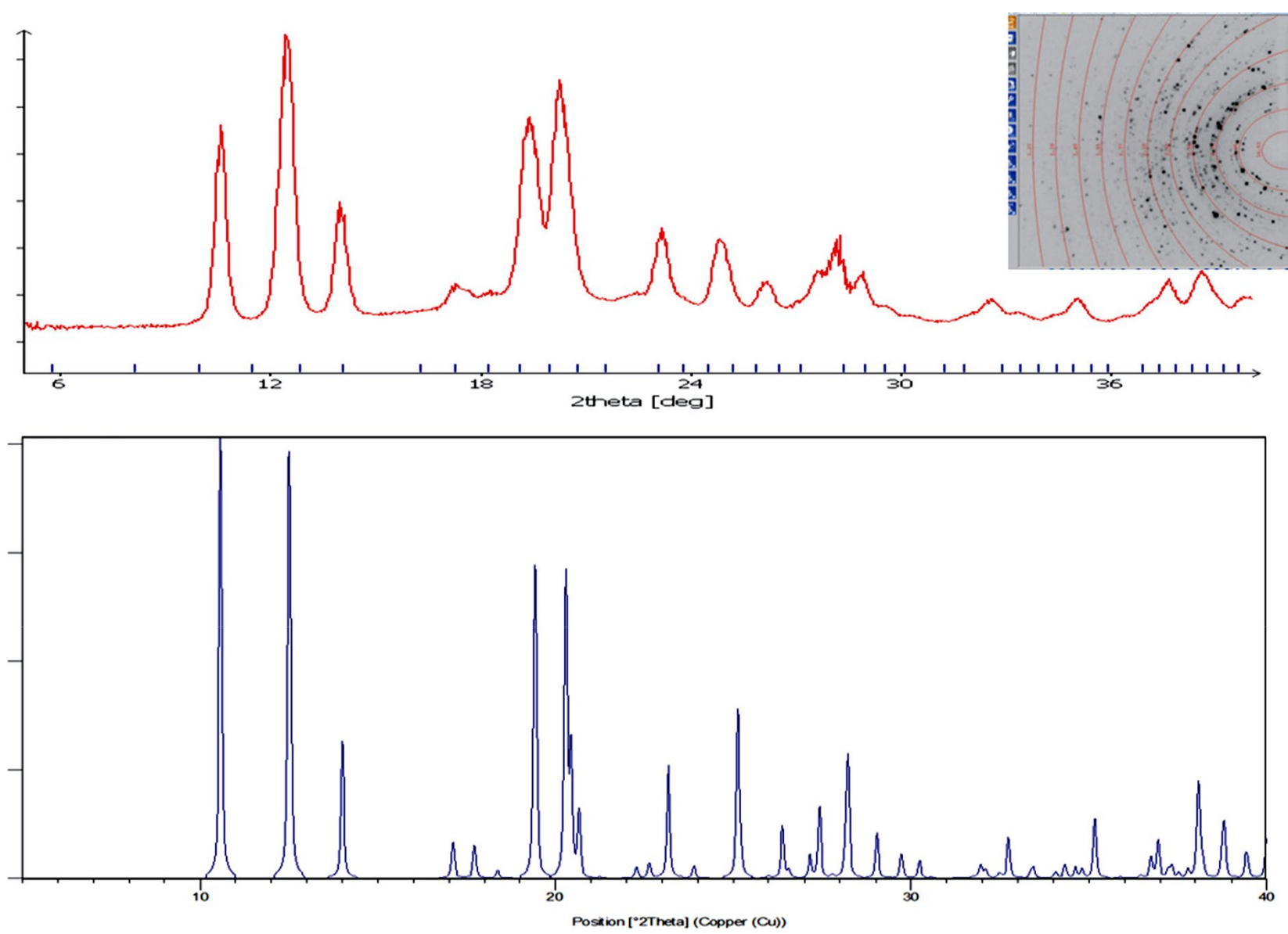

Figure 5. Upper graph represents the extraction of the powder pattern from the single crystal experiment, performed on opaque prism from Fig. S3. The powder pattern below is calculated from the crystal structure $\mathbf{2}$. By comparison of both patterns, the formation of $\mathbf{2}$ from $\mathbf{1}$ on air can be confirmed. Powder pattern extraction was performed by CrysAlis software. ${ }^{22}$

According to the observations, the structure conversion should not require significant reorganization of the atoms and molecules in the crystal. When comparing coordination environment of copper(II) in both title structures (cf. Figs. 1 and 2), the first difference between 1 and $\mathbf{2}$ can be observed in the apical ligand while the basal planes of the square pyramid remain mostly the same in both compounds; instead of pyridine in apical position in $\mathbf{1}$, a bridging methanoato ligand is present in $\mathbf{2}$ which enables the formation of polynuclear complex molecules. The second difference is in the presence of water in $\mathbf{2}$. One would expect that (i) the crystal packing of $\mathbf{1}$ should enable apical pyridine to leave the structure, and water to enter the structure simultaneously, and that (ii) monomeric coordination molecules should be arranged and oriented properly that the neighboring molecules can connect into chains via methanoato bridges. A drawing of molecular packing in $\mathbf{1}$ (Fig. 6) reveals that the apical pyridine ligands (drawn black) are located in virtual channels running along monoclinic $c$ axis. Through the latter the water molecules can enter while the pyridine ones can leave the structure. Crystal packing of $\mathbf{2}$ is represented in Fig. $7 \mathrm{~d}$. Considering the second requirement, at first glance molecules in $\mathbf{1}$ are not properly oriented to join themselves into chains as in $\mathbf{2}$ since the uncoordinated oxygen atoms of methanoato ligands are not oriented towards copper(II) ions. The proposed mechanism for the conversion of $\mathbf{1}$ to $\mathbf{2}$ is shown in Fig. 7: after removal of apical pyridines and entering of water the remaining coordination moieties rotate and move slightly to achieve an orientation that enables uncoordinated $\mathrm{O}$ atom of (every second) methanato ligand to coordi-

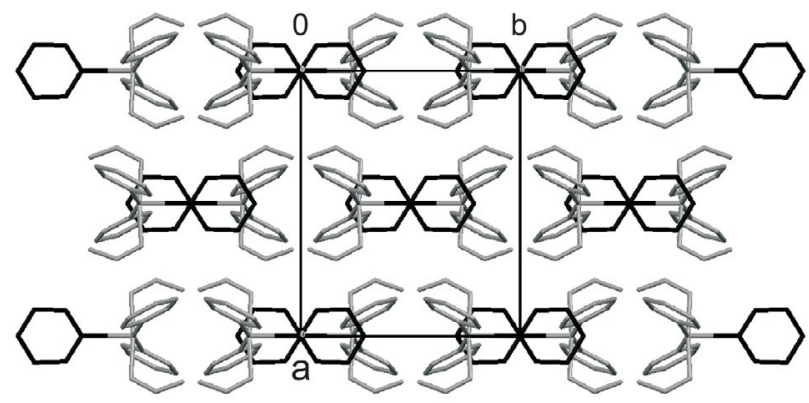

Figure 6. The packing of coordination molecules in $\mathbf{1}$; a view along $c$ axis. The channels through which the apical pyridine molecules (shown in black) can leave the structure and the water molecules enter it can be observed. Hydrogen atoms are omitted for clarity. 


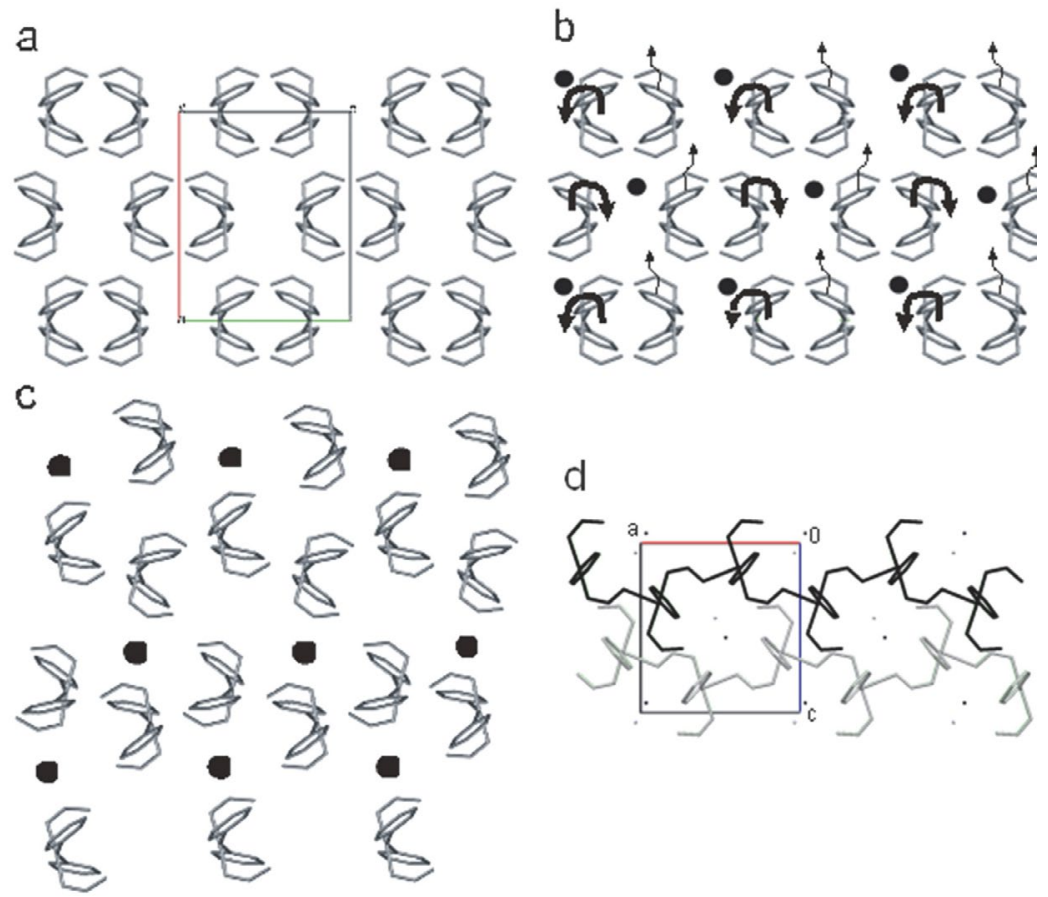

Figure 7. The proposed mechanism of conversion from 1 to 2. a) Pyridine molecules exit the structure of $\mathbf{1}$ (cf. Fig. 6), b) water molecules shown as black dots enter the structure, c) coordination moieties rearrange and consequently form chains to which water molecules are hydrogen bonded as in 2 (d). Narrow arrows show the direction of movement of complex molecules while the bold ones represent their rotations.

nate to neighboring $\mathrm{Cu}$ atom - making this way bridging methanoato ligands from the monodentate ones and consequently chains - to which the water molecules attach. All of proposed steps probably take place simultaneously.

\section{Conclusions}

Crystal structures of two methanoato copper(II) complexes with pyridine, i.e. $\left[\mathrm{Cu}\left(\mathrm{O}_{2} \mathrm{CH}\right)_{2}(\mathrm{Py})_{3}\right](\mathbf{1})$ and $\left[\mathrm{Cu}\left(\mathrm{O}_{2} \mathrm{CH}\right)_{2}(\mathrm{Py})_{2}\right]_{n} \cdot n \mathrm{H}_{2} \mathrm{O}(2)$ at $150 \mathrm{~K}$ were determined by single-crystal $\mathrm{X}$-ray diffraction. In both compounds, central $\mathrm{Cu}(\mathrm{II})$ is five-coordinated in a shape of square pyramid. In both complexes, the basal meanplane is formed by two nitrogens from coordinated pyridine molecules and two oxygens from two monodentately bound methanoato ligands. The apical atom is either nitrogen from the third coordinated pyridine molecule in $\mathbf{1}$ or oxygen from bridging methanoato ligand in $\mathbf{2}$. The distance $\mathrm{Cu}$-apical is about $0.25 \AA$ longer than the distances $\mathrm{Cu}$-equatorial. In 2 five coordinated copper(II) moieties are connected into chains through bridging methanoato ligands. To such chains water molecules are hydrogen bonded. Compound 2 was prepared in two ways: by heating copper(II) methanoate in pyridine and also from compound $\mathbf{1}$. The conversion from $\mathbf{1}$ into $\mathbf{2}$ was observed in the solution as well as in the solid state at exposure to water from air. Crystal packing in 1 enables entering of water and release of pyridine. Only little further structure reorganization is needed to achieve chain structure of 2 .

\section{Supplementary Materials}

CCDC 1019407 (1) and 1019408 (2) contain the supplementary crystallographic data. These data can be obtained free of charge from The Cambridge Crystallographic Data Centre via www.ccdc.cam.ac.uk/data_request/cif.

\section{Acknowledgements}

Financial support of the Ministry of Higher Education, Science and Technology of the Republic of Slovenia is gratefully acknowledged (grants P1-0175 and X-2000). The authors also thank Leja Erzin for optimization of syntheses.

\section{References}

1. D. A. Dickie, P. T. K. Lee, O. A. Labeodan, G. Schatte, N. Weinberg, A. R. Lewis, G. M. Bernard, R. E. Wasylishen, J. A. C. Clyburne, Dalton Trans. 2007, 2862-2869, and references therein. DOI:10.1039/b704588c

2. F. H. Allen, Acta Crystallogr. 2002, B58, 380-388. DOI:10.1107/S0108768102003890

3. M. A. Bernard, M. M. Borel, F. Busnot, A. Leclaire, Rev. Chim. Miner. 1979, 16, 124-133.

4. B. A. Cartwright, L. Couchman, A. C. Skapski, Acta Crystallogr. 1979, B35, 824-827. DOI:10.1107/S0567740879004982

5. B. Kozlevčar, E. Mate, Z. Jagličić, L. Glažar, A. Golobič, P. Strauch, J. Moncol, N. Kitanovski, P. Šegedin, Polyhedron 2009, 28, 2759-2765. DOI:10.1016/j.poly.2009.05.066 
6. M. Yamanaka, H. Uekusa, S. Ohba, Y. Saito, S. Iwata, M. Kato, T. Tokii, Y. Muto, O. W. Steward, Acta Crystallogr. 1991, B47, 344-355. DOI:10.1107/S0108768190012459

7. M. M. Borel, F. Busnot, A. Leclaire, Rev. Chim. Miner. 1977, 14, 286-294.

8. M. M. Borel, A. Busnot, F. Busnot, A. Leclaire, Rev. Chim. Miner. 1980, 17, 202-208.

9. B. Kozlevčar, L. Glažar, G. Pirc, Z. Jagličić, A. Golobič, P. Šegedin, Polyhedron 2007, 26, 11-16.

DOI:10.1016/j.poly.2007.08.019

10. G. A. van Albada, S. A. Komaei, H. Kooijman, A. L. Spek, J. Reedijk, Inorg. Chim. Acta 1999, 287, 226-231.

DOI:10.1016/S0020-1693(99)00010-9

11. M. A. Sharif, M. Tabatabaee, V. Beik, H. R. Khavasi, Acta Chim. Slov. 2012, 59, 289-293.

12. S. Esmaielzadeh, E. Zarenezhad, Acta Chim. Slov. 2018, 65, 416-428. DOI:10.17344/acsi.2018.4159

13. Y.-L. Sang, X.-S. Lin, Acta Chim. Slov. 2019, 66, 168-172.

14. N. Burger, H. Fuess, Solid State Commun. 1980, 34, 699-703. DOI:10.1016/0038-1098(80)90959-X
15. Collect Software. Nonius BV. Delft, The Netherlands, 2000.

16. Z. Otwinowski, W. Minor, Methods Enzymol. 1997, 276, 307326. DOI:10.1016/S0076-6879(97)76066-X

17. A. Altomare, M. C. Burla, M. Camalli, G. L. Cascarano, C. Giacovazzo, A. Guagliardi, A. G. G. Moliterni, G. Polidori, R. Spagna, J. Appl. Crystallogr. 1999, 32, 115-119. DOI:10.1107/S0021889898007717

18. SHELXL2013. G. M. Sheldrick, University of Göttingen, Germany, 2013.

19. L. J. Farrugia, J. Appl. Crystallogr. 1997, 30, 565-565. DOI: $10.1107 /$ S0021889897003117

20. C. F. Macrae, P. R. Edgington, P. McCabe, E. Pidcock, G. P. Shields, R. Taylor, M. Towler, J. van de Streek, J. Appl. Crystallogr. 2006, 39, 453-457. DOI:10.1107/S002188980600731X

21. A. W. Addison, N. T. Rao, J. Reedijk, J. van Rijn, G. C. Verschoor, J. Chem. Soc., Dalton Trans. 1984, 1349-1356. DOI:10.1039/DT9840001349

22. Agilent (2014). CrysAlis PRO. Agilent Technologies Ltd, Yarnton, Oxfordshire, England.

\section{Povzetek}

Iz reakcijske raztopine, ki je vsebovala suh piridin in dvojedrni $\left[\mathrm{Cu}_{2}{ }_{2}{ }^{\mathrm{I}}\left(\mathrm{O}_{2} \mathrm{CH}\right)_{4}(\mathrm{Py})_{2}\right]$, smo pripravili modre prizmatične kristale enojedrne spojine $\left[\mathrm{Cu}^{\mathrm{II}}\left(\mathrm{O}_{2} \mathrm{CH}\right)_{2}(\mathrm{Py})_{3}\right]\left(\mathrm{Py}=\right.$ piridin, $\left.\mathrm{C}_{5} \mathrm{H}_{5} \mathrm{~N}\right)$, 1. Ko smo del reakcijske raztopine izpostavili zračni vlagi, so se kristali 1 najprej raztopili v matični lužini, hkrati pa so iz raztopine zrasli modri igličasti kristali $\mathbf{2}$, tj. kristali kovalentno povezane verižne strukture s formulo $\left[\mathrm{Cu}\left(\mathrm{O}_{2} \mathrm{CH}\right)_{2}(\mathrm{Py})_{2}\right]_{n} \cdot n \mathrm{H}_{2} \mathrm{O}$. Proces, ki je bil zaključen v nekaj minutah, smo opazovali pod optičnim mikroskopom. Pretvorba iz 1 v 2 se zgodi tudi v trdnem stanju izven raztopine. Uklonsko sliko monokristalov smo posneli pri $150 \mathrm{~K}$, in sicer najprej za strukturo $\mathbf{1}$ ter nato še za $\mathbf{2}$ iz iste reakcijske raztopine. Opisana je tudi alternativna sintezna metoda iz zmesi bakrovega metanoata in piridina za pripravo 2.

Except when otherwise noted, articles in this journal are published under the terms and conditions of the Creative Commons Attribution 4.0 International License 